\title{
Lithuanian Literature in 1918-1940: The Dynamics of Influences and Originality
}

\author{
GITANA VANAGAITÉ
}

\begin{abstract}
Lithuanian independence (1918-1940), which lasted for twentytwo years, and its symbolic center, the provisional capital Kaunas, have been very important for the country's political, social, and cultural identity. In 1918, changes in the social, economic, and political status of an individual as well as transformations in the literary field followed the change of the political system. In what ways the relationship between the center and the periphery and the spheres of literary influences were altered by the new forms of life? Lithuania, the former geographic periphery of tsarist Russia, after the change of the political system became a geographical and cultural periphery of Europe. Nevertheless, political freedom provided an opportunity to use the dichotomy of center-periphery creatively. Lithuanian writers, who suddenly found themselves living in Europe with old cultural traditions, tried to overcome the insignificance of their own literature, its shallow themes and problems by "borrowing" ideas and ways to express them. In fact, the imitation was not mechanical, so the new influences enabled writers to expand significantly the themes and forms of Lithuanian literature.

The article examines the development of new cultural centers in independent Lithuania. It also discusses the avant-garde movement which emerged under the influence of Russian futurists and German expressionists. In addition, it focuses on individual authors, such as Antanas Vaičiulaitis, Kazys Binkis and Petras Cvirka, and the influence that affected their works.
\end{abstract}

Keywords: center; periphery; literary influence; host culture

\section{Center and Periphery in Literature}

The word periphery translated from the Latin (peripheria) means "a circle." In turn, this Latin word is related to two Greek words, perí, which means "around," and pherein - "to carry". The Italian poet Giacomo Leopardi captured the main nuance of the meaning of this word. Periphery is when the radius of any circle comes in and joins in the center of that circle. On the other hand, periphery is etymologically and semantically almost identical to province, which we define 
as small centers situated far from the main center. Province, like periphery, is the word of Latin origin consisting of the preposition pro (meaning "for" or "on behalf of") and the verb vincere ("to defeat"). The residents of Rome were the first to use this concept. Initially, they used it for the territories they conquered, which were ruled by the specially appointed deputies and paid taxes to the center. Later, provinces meant the distant and non-Roman regions of the Roman Empire (trecani.it).

The concept of Lithuania as a geopolitical province and a long-standing north-west region of tsarist Russia was especially affected by the administrative reform carried out under Peter I in 1711-1719, which divided the territory into provinces. Later, the concept of the province acquired a more general geographic meaning as it was used for the territories situated far from the centers of Moscow and St. Petersburg.

In literature, the dichotomy of periphery and center can be applied to analyze various literary phenomena, the change and evolution of genres, themes, styles, etc. It can also be used to explore the cultural and literary links and influences among different countries. Representatives of Russian formalism were among the first ones to start to explain the dynamics in literature using these concepts. Yury Tynyanov pointed out "literary fact" and "fact of everyday life" as important categories in describing the dynamics between the center and periphery in the article "Literary Fact" (“Аитературный факт", 1924). According to Tynyanov, the "fact of everyday life" has its own structure and activity. Its forms, at least under certain historical circumstances, have a direct influence on the development of literature. Thus, the "fact of everyday life" can be perceived as reserves of literature. This dialectical interdependence of "literary fact" and "fact of everyday life" determines that literature is structured by the center and the periphery that can interchange:

Journals, almanacs, existed before our time, too, but only during our time have they become recognized as a specific "literary work" a "literary fact." "Transsense language" (заумь) always existed in children's language, the language of some [religious] sectarians, etc. And the opposite is also true: what today is a literary fact, tomorrow becomes a simple fact of everyday life, it disappears from literature. Charades, logogriphs - are to us children's games, but in the era of Karamzin [late 18th-early 19th cc., GH] with its emphasis on verbal trivia and play with devices, they were literary genres. And not only are the borders of literature, its periphery, its liminal regions, fluid, but so is the very "center." It is not a matter of some primeval, major stream moving and evolving in the center of literature, while only at the edges new phenomena flow in - no, these new phenomena appear in the very center, and the center itself moves away to the periphery. (Tynianov 2010) 
The idea that the literary center is not stable relates to the fact that the literary tradition, the literary system or the hierarchy are the constantly changing dimensions. T. S. Eliot states this idea in perhaps the most famous of his articles, "Tradition and the Individual Talent" (1919). He argues that a poet enters the already existing tradition and must find his or her own place in it:

The existing monuments form an ideal order among themselves, which is modified by the introduction of the new (the really new) work of art among them. The existing order is complete before the new work arrives; for order to persist after the supervention of novelty, the whole existing order must be, if ever so slightly, altered; and so the relations, proportions, values of each work of art toward the whole are readjusted; and this is conformity between the old and the new. Whoever has approved this idea of order, of the form of European, of English literature, will not find it preposterous that the past should be altered by the present as much as the present is directed by the past. And the poet who is aware of this will be aware of great difficulties and responsibilities. (Eliot 1919)

Thus, the field of literature is broad, and its boundaries, as well as the space of the center and the periphery, are constantly changing. But Antoine Compagnon, a French literary scholar, asserts that the criteria for including certain texts in literature are often not literary: "The criterion of value that includes one text or excludes another is not in itself literary or theoretical but ethical, social, and ideological, in any case extra-literary" (Compagnon 2004: 19). The two perspectives of perceiving literature complement each other in their attempts to define literature and the changes in and tensions between its center and periphery. One of them, in Compagnon's words, is a contextual perspective (historical, psychological, sociological, and institutional); another one is a textual perspective (linguistic) (Compagnon 2004: 16). These perspectives became modified at a turning point in linguistics when tension heightened between the external and the internal definitions of literature.

Gérard Genette joined this discussion in his study Fiction and Diction (first published in 1991). Looking for answers to the questions about literature and literariness, phrased by Roman Jakobson, Genette defines literariness as a plural phenomenon which requires a pluralist theory. He defines literariness using three aspects: its regimes, criteria, and modes. According to him, there exist two regimes of literariness. A constitutive or essentialist "is underwritten by a complex of intentions, generic conventions, and cultural traditions of all sorts" (Genette 1993: vii). It is independent of any judgment (a sonnet is a sonnet, a novel is a novel) and is closed. 
The conditional regime, "which arises from a subjective and always revocable aesthetic appreciation" (an autobiography appreciated of its style, a novel that revolutionizes narrative technique), is a more open regime. These regimes intersect with two criteria: thematic (what the text is "about"), relative to the content of the text, and rhematic, relative to the character of the text itself and to the type of discourse it exemplifies (poetry or prose). Regime and criterion combine to form two modes of literariness: fiction, defined by the imaginary nature of its objects, and diction, characterized by its formal traits. The common feature between the two modes is their transitivity, fiction being pseudo-referential and diction - a form of discourse in which "signification is inseparable from verbal form." (Genette 1993: vii-25)

Since literature develops as a field with the center and the periphery, to apply Genette's literary regimes one can say that the literary center, which is closed and stable, is related to the constitutive regime. The periphery, associated with the conditional regime, is open and fluid. If the literary center contains works that are considered to be literary, regardless of their aesthetic value because even bad literature is literature, then the periphery consists of works that are generally not considered literary, but under certain circumstances they migrate from the periphery to the center of literature. Genette refers to the texts of Demosthenes and Jules Michelet, which "for certain readers" are "an incontestable aesthetic object, but the term work of art, whose definition implies an aesthetic intention, as well, cannot be applied literally in this case." (Genette 1993: 28) In the article "Literary Fact," Tynyanov mentions letters which belonged to the periphery to become the center of literature. Today, some of these letters are read and quoted as if they were literature, completely ignoring the fact that once it was just correspondence between two people.

Thus, the center and the periphery of literature, or in the words of Tynyanov, the "literary fact" and the "fact of everyday life," or Genette's constitutive or conditional literariness, constantly exchange their semantic complexes. According to Tynyanov, the connection between these complexes shows a twoway dialectical relationship between the center and the periphery in culture.

\section{Lithuanian Cultural Centers before Independence}

Lithuanian literature cannot boast about its old traditions, if to perceive literature from a modern perspective as a written form of art in pursuit of aesthetic goals. No doubt that from the geopolitical point of view, Lithuanian literature is a peripheral literature. It is the periphery which was and perhaps still is influenced by various Western and Eastern cultural centers. The fact 
is that the country was subjected to oppression or occupations, when because of the political situation the influences of a certain center were compulsory and free centers were out of reach. The article mainly focuses on Lithuanian literature within the period 1918-1940, i.e. the period of independence that was defined not by cultural, but political events.

Lithuania restored its independence in 1918 after more than 120 years of the oppression of tsarist Russia, let alone various political unions with Poland before that oppression. The year of 1940 marks the loss of independence and the beginning of Soviet occupation. Life in independent Lithuania, which lasted for 22 years, has been very important to Lithuania's current political and cultural self-perception. In 1918, when the independence was restored, the cultural situation in the country was terrible. Lithuanians entered the independence with the mentality of banned Lithuanian alphabet, Lithuanian schools, and religion. This ban and the purposeful policy of Russification included all spheres of life and lasted for 40 years since the uprising of 1863 when tsarist Russia banned Latin alphabet in favor of Cyrillic. At the same time, the only university in the country that had been founded in Vilnius was closed. It was reopened only in 1919 when Poland occupied Vilnius and its region.

Until 1904, when the press ban was lifted, the main task of Lithuanian culture and literature was to resist the ban and maintain national identity instead of creating fiction or modern literary or cultural forms as it was the case in Western Europe. Therefore, at the beginning of the $20^{\text {th }}$ century with the abolition of the ban, although the country was still part of tsarist Russia, there was no need to protect Lithuanian culture from extinction. It was time to embrace the culture of Western Europe.

The turn of the $20^{\text {th }}$ century was a very intense and important time in Lithuanian culture. At that time, a very powerful wave of modern movements from the West and East reached Lithuania. The modernist period in Polish visual arts, literature and music, "Młoda Polska," covering the years between 1890 and 1918, had a very important influence on Lithuanian culture. Therefore, the beginning of the $20^{\text {th }}$ century witnessed a dynamic change of literary periphery and centers that resulted in the coexistence of old literary forms, such as Classicism, Sentimentalism, Educational Rationalism, and Realism, and various new modern literary trends, such as Impressionism, Symbolism, and later avant-garde, in culture and literature.

But can the cultural distance between small provincial Lithuania, which for political reasons started its cultural path rather late, and the cultures of major centers be overcome? In what way can this distance, which includes civilizational, intellectual and mental differences, aesthetic and philosophical orientation, and ultimately the language in which all these things are expressed, 
be covered? If it can be covered, then how? On the other hand, maybe there is no distance at all? Maybe the seeming necessity to chase major centers is psychological or illusory? Maybe in search of its authenticity and originality, culture has to take its own path, even if it is minor and peripheral? Maybe then centers will get interested in peripheries?

On the other hand, it is a question how the center-periphery dichotomy appears in the field of Lithuanian literature. For example, the first mass emigration from Lithuania to America began around 1868. Lithuanians were leaving because of two unsuccessful uprisings and famine caused by poor economy; in addition, men tried to escape 25 years of compulsory military service in the Russian army. It is estimated that about 500,000 people left Lithuania before the First World War (Eidintas 1993: 23). The majority of the emigrants were illiterate or barely literate peasants, who in the United States found jobs in mines, foundries, slaughterhouses, and pits. Most of them did not speak English; therefore, they, with few exceptions, did not participate in American life. All emigrants congregated in their ethnic groups. Based on those groups, Lithuanian communities, political and cultural societies were established, churches were built, Lithuanian schools were founded, and Lithuanian newspapers were published. At that time, the first theater groups appeared. No doubt theater to an uneducated and almost illiterate person was more understandable and accessible than a book or a newspaper.

However, the enthusiasm of several educated individuals resulted in publishing the first Lithuanian newspaper, Gazieta Lietuviška (The Lithuanian Gazette), in America, in August, 1879. The newspaper ran for only five months, and because it did not survive to our days, various sources claim that a total of 12-16 issues were published, yet in Lithuania, the first newspaper was published four years later, in 1883. The newspaper Auszra, published by Jonas Basanavičius, was printed in Ragainè (today Neman, Russia) and Tilžè (today Sovetsk, Russia). It was secretly transported to Lithuania by book smugglers.

The first Lithuanian play was also staged in America in 1889. Bronius Vaškelis, who examined the development of Lithuanian theater in America, points out that attempts were made to put on a play even earlier, but they were unsuccessful. The very beginning of such attempts could be attributed to Jonas Šliūpas, who witnessing the success of Polish, German, and Jewish theater groups in New York, began organizing a Lithuanian performance at the beginning of 1885 . Despite the challenging rehearsals and even a few attempts to perform a play, the premiere was delayed a couple of times at the beginning of 1887. In the end, the performance never took place (Vaškelis 1989: 121).

The second attempt was more successful. In 1889, Lithuanians in Plymouth, led by the priest Antanas Burba, separated from the Poles and founded their 
own Lithuanian church. According to Vaškelis, several Polish theater groups were active in the Pennsylvania mine area, and apparently Burba had the idea to use theater as a weapon against the Poles. Together with Antanas Turskis and Juozas Paukštis, he gathered 26 people willing to participate, mainly employees at the Paukštis Publishing House. They performed Turskis's play, Be sumnenés arba kajp ejnasi ant swieto (Without Conscience), on December 31, 1889. The plot of the play is based on farmer Jacob's unsuccessful emigration story (Vaškelis 1989: 121).

Meanwhile in Lithuania, the first public performance of the play Amerika pirtyje (America in the Bathhouse) by Keturakis was staged 10 years later, on August 20, 1899, the press ban being still in effect. The play was performed in Palanga, in Count Tiškevičius's warehouse, located on the seafront. Although the official governor's permit to perform was obtained, since the comedy was considered critical of the tsarist regime, all the performers were arrested. The performance became not only an important cultural but also political event, and it was used as a tool in the struggle for freedom. In America, the comedy written by the Vilkutaitis brothers, Antanas and Juozas, ${ }^{1}$ was staged three years earlier than in Lithuania, in 1895 (Vaškelis 1989: 128). Until its first performance in Lithuania, it was performed at least five times by different Lithuanian communities in the United States.

The Lithuanian diaspora in America initiated and funded more initiatives that were very important for Lithuanian culture under prohibition. They organized a contest of Lithuanian grammar ${ }^{2}$, actively supported financially and

1 In 1893, Vincas Kudirka announced a Lithuanian drama contest in the newspaper Varpas. The Vilkutaitis brothers, Antanas and Juozas, wrote the comedy Amerika pirtyje (America in the Bathhouse) and signed it with the pseudonym Keturakis, i.e. having four eyes. Subsequently, the question of the authorship became very controversial, and it has never been fully established.

2 At the beginning of the $20^{\text {th }}$ century, American Lithuanians felt a need to have a grammar of the Lithuanian language because it was used chaotically and without any rules. The Lithuanian Alliance of America launched a contest to write the best grammar rules for the Lithuanian language. A medical student, Petras Avižonis, having heard about it at Dorpat University (Tartu), began to write a textbook. But after running into difficulties, during the summer holidays, he visited the famous linguist Jonas Jablonskis. The Grammar of the Lithuanian Language was published in 1901 in Tilže under the pseudonym Petras Kriaušaitis. Two authors hide behind the pseudonym: the first name belongs to Petras Avižonis (because of his previous Lithuanian activities, he could not use his last name), while Jablonskis signed as Kriaušaitis (he could not use his old pseudonym, Obuolaitis, because it was uncovered by the authorities). The two divided between themselves $\$ 50$, the prize awarded by the Lithuanian Alliance of America. The print run of the grammar was 3000 copies; 2600 were sent to America and 400 went to Lithuania (Reneckis 2018). 
with displays Lithuania's exhibition in the world fair of 1900 held in Paris. "The exposition emphasized book publishing and press ban; the figures were presented, showing the number of publications printed by Lithuanians in the United States and what part printed in Minor Lithuania they financed. In the long run, it became clear that it was cheaper to print books in Tilže than to have them shipped from America." (Reneckis 2018)

This situation suggests that during the years of tsarist Russia oppression, the cultural and literary center of Lithuania was in America where emigrants had much better conditions to act. But is it really true? Did this center have any influence on culture in Lithuania that suffered from the oppression? Perhaps in this case, we should talk about two centers, active and passive, united by the same intention to spread Lithuanianism but acting in different ways because of the political situation.

\section{Creative Transformations of Influences during the Years of Independence}

The center-periphery dichotomy appears in an absolutely different light when analyzing the literature of independent Lithuania. After 1918, new forms of life provided an individual with certain social, economic, and political security. The shift in the political system changed the status of a writer and literature. There was no need for didactic and national functions in literature. The direct contact with Russia and Poland, which dominated at the beginning of the $20^{\text {th }}$ century, shifted toward Western Europe. For example, the opening of the border with Germany and extremely high post-war inflation, made Lithuanians travel west to publish books and to study.

The first organized literary movement in independent Lithuania is associated with a group of young avant-garde writers that in 1922-1928 published the avant-garde magazine Keturi vejai (Four Winds). Another avantgarde group was "Trečias frontas" (Third Front) (1930-1931), which opposed the authoritarian regime of Antanas Smetona. Both groups in the context of historical European avant-garde movements were neither authentic nor original. Often the creative potential of the Lithuanian avant-garde fell short of the Russian, German or Polish avant-garde. Aušra Jurgutienè observes that they did not always adequately meet Western European avant-garde aesthetic programs and artistic forms (Jurgutienè 1996: 86).

Lithuanian avant-garde was greatly influenced by German expressionism and Russian futurism. Vladimir Mayakovsky, in particular, had a huge influence on Petras Tarulis (Juozas Petrenas), the editor of Four Winds. The 
first issue of the magazine was sent to Mayakovsky, "a friend and teacher" (Gudaitis 1986: 79). A certain degree of influence of Mayakovsky or German expressionists can be identified not only in Tarulis, but also other avant-garde artists' works, for example, Kazys Binkis, Salys Šemerys, Balys Sruoga, or Kazys Boruta. The influence manifests itself in stylistics, a choice of certain themes, motifs, or images. However, Vytautas Kubilius, who analyzed the links between the Lithuanian avant-garde and German expressionists, states:

The brotherhood of the "Four Winds" did not become a typical expressionist movement, as K. Binkis had planned right after his arrival from Berlin. The joyous guys did not relate to the tensions of the global crisis, raging death, condemnation, and alienation, which the German expressionists brought from the trenches. When R. Goering and G. Heym proclaimed that "there is no God" and that "the sky is deaf, bare, and empty," these philosophical categories were full of rage and desperation, but [they were] completely alien to the loud mentality of the representatives of the "Four Winds." [...] The brotherhood of the "Four Winds" lacked the pathos of truly enduring ideas and spiritual authenticity that determined the creative power of the expressionists, and, therefore, they could not shock the reader [...]. (Kubilius 1983: 122)

Although expressionism was slowly spreading in Lithuania, the avant-garde movements did not become independent centers of literature. Despite the fact that they contributed to the poetic revolution, they remained more on the periphery. Along with the avant-garde, symbolism was evolving in Lithuania, and the poetics of Romanticism thanks to Maironis was also significant. These tendencies competed with each other, proving the idea about the sequential development of literary trends or movements, based on the history of Western European literature, wrong. Literary scholars in their studies of Eastern European literature, accept it as contradictory to the Western model that is considered to be a norm. Therefore, it is said that "the Slavic literary process in the modern period" was "late" or "fast" or "dense" (Zürcher 1998: 127). The development of Slavic literature is really exceptional:

In Slavic literatures, the hybrid style is a feature of the evolution of literature, which distinguishes these literatures from the prevailing western literary process model and represents a different mode of writing and evolution. (Koschmal 1993: 77, qtd. in Zürcher 1998: 127)

Christoph Zürcher, discussing Lithuanian avant-garde, relies on Peter Zajac's pulsating model described in the essay "Is There Anything like a Pulsating 
Literary History?" (1993) This model, which contradicts the linear one, helps to better understand turning points in literature because in literature various parts of the system are mixed, "perhaps even the boundaries between their traditional functions (when a non-literary category gets into the center of the literary movement, etc.) disappear. Different types of movements, separated from each other by stable situations of systems, appear side by side; the "new" mixes with the "old," seeking new solutions that do not always have to win recognition but become valuable due to "the energy of error" (V. Shklovsky)" (Zajac: 1993 27, qtd. in. Zürcher: 1998, 129).

The pulsating model makes it possible to perceive literature as a combination of several simultaneous centers, which under the influence of major literary centers, temporarily push aside or adjust the dominant local literary model. In the independent Lithuania, this function was performed by Symbolism and avant-garde. They clashed with Romanticism that occupied the central position in literature. ${ }^{3}$ However, the romantic way of thinking, briefly pushed to periphery, remained predominant. This tendency was demonstrated by a group of young people who grew up and graduated in the independent Lithuania and in the late 1920s began to publish neo-romantic aesthetics publications: the journal Pjūvis (A Cut) in 1929 and the almanac Granitas (Granite) in 1930.

Thus, the first organized avant-garde movement and Symbolism that developed alongside it reached Lithuania 20-30 years late. Although the imitation of the center's culture is obvious, Lithuanian representatives of these trends often imitated only separate elements of trend aesthetics or philosophy and created a lot of authentic and original poetry. Perhaps the greatest influence of other cultures can be observed in the arsenal of images related to civilization and urban culture: speed, violence, alienation, engines, locomotives, radio, etc. However, Lithuanian poets, using borrowed images, were able to create unique and original meanings. They are especially vivid in the lively image of Lithuanian nature, spring, and wind in particular. The very name of the group, "Four Winds," was like a key to the entire movement, a symbol of freedom that "the representatives of the movement chose to express their worldview. This symbol also corresponds to their literary efforts to be savage or playful, sometimes even aggressive, but never dogmatic" (Zürcher 1998: 65). On the other hand, the wind, traveling in all directions, was supposed to compensate for the almost non-existent layer of civilization.

3 In 1927, a lively discussion about the future of Romanticism took place in Lithuanian literary press. Famous Lithuanian writers, such as Vaižgantas and Vincas MykolaitisPutinas, participated in it. 
Lithuanian avant-garde artists did not have to destroy academies, museums, or universities ${ }^{4}$ because then they started to be established. Perhaps that is why Lithuanian avant-garde followed the tradition more than their articles declared. For example, they openly embraced folklore and old literature, and their worldview, as Zürcher notes, remained extremely archaic, rough, and uncivilized (Zürcher 1998: 23).

On the other hand, after the proclamation of independence, an opportunity to take a different look at Lithuanian literature presented itself. Besides the usual aspiration to revive the nation and support it during the years of oppression, aesthetic goals were set for literature. There was a clear understanding of how far Lithuanian literature had fallen behind European literature, which had already endured the modern epoch. It was necessary to learn to portray a human being in a different way and to narrate other things about him. In this process, the influence of cultural centers proved to be very strong, especially in form. For example, the end of the short story "Šiaurietè" ("The Woman from the North", 1939) by Antanas Vaičiulaitis by its content, motives, and style is similar to the play The Blind (1891) by Maurice Maeterlinck. Although Vaičiulaitis rewrote the end of the story a couple of times, he was apparently too much fascinated by Maeterlinck's ability to create the tense atmosphere of approaching death. The Lithuanian author not only borrowed some of Maeterlinck's images (loose shutter in the wind, the clock that stopped), but also the anxiety of waiting, which is almost identical to the end of Maeterlinck's play. Despite this obvious influence, Vaičiulaitis wrote a wonderful and compelling piece of art. Its themes, related to the specifics of Lithuanian countryside, can be analyzed on the universal level of modern perception, raising questions of choice and responsibility that are irrelevant to Maeterlinck's work.

The obvious influence of Luigi Pirandello's play, Sei Personaggi in cerca d'autore (Six Characters in Search of an Author, 1921), can be traced in the works of Kazys Binkis, the founder of the Lithuanian avant-garde movement. Pirandello's work inspired Binkis's play Generaline Repeticija (The Dress Rehearsal, 1940). On the other hand, Pirandello is the author who introduced the problem of the relationship between reality and artistic reality, vital to modernism. Everything else in Binkis's play, i.e. the theme, the conflict, etc., has no similarities to Pirandello's play. The Lithuanian playwright considers

\footnotetext{
Vilnius University, which was closed after the 1861 uprising, was opened in 1919 by Polish authorities. Independent Lithuania opened its first university in Kaunas in 1922. Originally called the University of Lithuania, it was renamed to Vytautas Magnus University in 1930.
} 
the encounter between a man and war, the clash between small and powerful, whereas Pirandello seems to have gone much further - he contemplates how modern thinking has changed human perceptions.

A widely accepted notion in the history of Lithuanian literature is that Petras Cvirka wrote his novel Meisteris ir sūnūs (The Master and His Sons, 1936) following the novel Colas Breugnon (1914) by the French writer Romain Rolland (Naujokaitis 1976: 475). Balys Sruoga, the first one to note it, wrote about the similarities in his ironic review "A Peach in Lithuania," (Sruoga 1937) right after the novel was published. In his long review, Sruoga, who had translated fragments of "Colas Breugnon" to Lithuanian, meticulously records all the obvious similarities. The likeness between the two novels does exist; for example, some of the plot lines and events are similarly constructed, and the hero's fate is interpreted in almost the same way, but the form is different. Rolland chooses a first-person narrator's point of view and uses a lot of metafictional comments. Cvirka's novel is more traditional: He maintains the chronology of events but tries to depict the life of the main characters using multiple point of view.

Perhaps the biggest difference between the novels can be seen at the lexical level. Cvirka's language is colorful and rich, while Rolland, although he said that "he wanted to write a 'funny' story, in order to take a break from the multivolume Jean-Christophe's tranquility, does not inject the wittiness, the variety, or the snappiness, which is abundant in Cvirka's work" (Ciplijauskaite 2005: 26). Therefore, Ciplijauskaite observes that the reference to "Colas Breugnon" in the case of Cvirka's novel is not essential. It has an entirely different mode of narration and employs other points of view and situations.

\section{Toward Conclusions}

Many similar influences are characteristic of the interwar Lithuanian literature. Writers, who suddenly found themselves living in Europe, realized the smallness of their literature and the narrowness of literary themes and problems. Therefore, borrowing was an opportunity to catch up with the literature that followed a different path. However, the imitations and influences were not mechanical and were used creatively. On the other hand, in Hans Georg Gadamer's view, only those who are ready and receptive can be affected. Indeed, the host culture needs to feel the lack of and the need for certain ideas or forms, and only then, after recognizing these ideas or forms in another culture, it will import them. "Finally, influences are experienced because what influences is close and effective” (Gadamer 1999: 5). 
VANAGAITE்

In addition, because of the new and faster forms of communication in the $20^{\text {th }}$ century, influences and parallels were more frequent, evident, and spread more rapidly. However, modern literature, while preserving certain features characteristic of all European literatures, retained the peculiarities of every nation by keeping its internal forms and meanings. This is the case with the literature of independent Lithuania. After experiencing the influence of major literary centers, young Lithuanian literature was able to establish its own centers (though peripheral ones), which although they had long ceased to exist physically (after the occupations of the 1940s), remained alive in people's mind.

\author{
Gitana Vanagaitè \\ gitana.vanagaite@vdu.lt \\ Vytauto Didžiojo Universitetas \\ Švietimo akademija \\ T. Ševčenkos 31-216 \\ LT-03111 Vilnius \\ LIETUVA / LITHUANIA
}

\title{
References
}

Ciplijauskaitè, B. 2005. Meisteris (Icchokas Meras) ir jo sūnūs (variacijos Petro Cvirkos temomis). - Colloquia, 15, 25-32.

Compagnon, A. 2004. Literature, Theory, and Common Sense. Trans. C. Cosman. Princeton University Press.

Eidintas, A. 1993. Lietuvių kolumbai: lietuvių emigracijos istorijos apybraiža. Vilnius: Mintis.

Eliot, T. S. 1919. Tradition and the Individual Talent. - http://www.bartleby.com/200/ sw4.html (16.12.2017).

Gadamer, H. G. 1999. Istorija. Menas. Kalba. Vilnius: Baltos lankos.

Genette, G. 1993. Fiction and Diction. Trans. C. Porter. Ithaca: Cornell University Press.

Gudaitis, L. 1986. Permainu vejai. Lietuviu literatūrinè spauda 1923-1927 metais. Vilnius: Vaga.

http://www.treccani.it/vocabolario/periferia/ (20.12.2017)

Jurgutienè, A. 1996. Neoromantizmas ar simbolizmas? - Lituanistica, 1 (25), 80-97.

Koschmal, W. 1993. Die slawischen Literaturen - ein alternatives Evoliutionsmodel. - Wiener slawistischer Almanach, 32, 69-88.

Kubilius, V. 1983. Lietuvių literatūra ir pasaulinès literatūros procesas. Vilnius: Vaga.

Naujokaitis, P. 1976. Lietuvių literatūros istorija, t. 3. Čikaga: JAV LB Kultūros Taryba.

Reneckis, A. 2018. „Pasiliksiu lietuviuose“. - https://www.lzinios.lt/lzinios/Kultura-irpramogos/arvydas-reneckis-pasiliksiu-lietuviuose-/259716 (20.12.2017).

Sruoga B. 1937. Persikas Lietuvoj. - Akademikas, 11-12, 248-255. 
Lithuanian Literature in 1918-1940

Tynianov, I. 2010. Literary Fact. Translated hastily by Gitta Hammarberg, https:// www.macalester.edu/ hammarberg/russ294littheory/TynianovLit\%20fact.html (29.12.2017).

Vaškelis, B. 1989. Lietuvių teatro JAV pirmasis dešimtmetis 1889-1899. - Metmenys, 40, 120-152.

Zajac, P. 1993. Existiert so etwa wie eine Pulsationsliteraturgeschichte? - Wiener slawistischer Almanach, 32, 21-32.

Zürcher, Ch. 1998. Lietuvių avangardo pavasaris. Vilnius: Lietuvių literatūros ir tautosakos institutas. 